\title{
CLINICAL, RADIOGRAPHIC AND HISTOLOGICAL EVALUATION OF CHRONIC PERIAPICAL INFLAMMATORY LESIONS
}

\author{
AVALIAÇÃO COMPARATIVA CLÍNICO-RADIOGRÁFICA E HISTOPATOLÓGICA DE LESÕES \\ PERIAPICAIS INFLAMATÓRIAS CRÔNICAS
}

\begin{abstract}
Raphael Carlos Comelli LIA ${ }^{1}$, Juliana Máira Q. GARCIA ${ }^{2}$, Manoel D. SOUSA-NETO ${ }^{1}$, Paulo César SAQUY ${ }^{1}$, Renata Hebling MARINS², Wagner Grandinni ZUCOLLOTTO ${ }^{3}$
\end{abstract}

\author{
1- DDS, PhD, Dental School,, University of Ribeirão Preto. \\ 2- DDS, MSc, Dental School,, University of Ribeirão Preto. \\ 3- Undergraduate student of Dental School, University of Ribeirão Preto.
}

Corresponding address: Manoel D. Souza-Neto - R. Célia de Oliveira Meirelles, 350 Ribeirão Preto - CEP- 14024-070

e-mail: sousanet@unaerp.br

Received: August 8, 2003 - Returned for modification: October 6, 2003 - Accepted: March 1, 2004

\begin{abstract}
$T_{\mathrm{h}}$

Le aim of the present study was to comparatively evaluate the clinical, radiographic and histological aspects of chronic inflammatory periapical lesions. One hundred and sixty-four lesions of human teeth, independent of age, race and sex, were evaluated by clinical, radiographic and histological analyses conducted after surgical endodontic treatment. Our results showed that there was uniformity in the interference factors on the evolution of periapical healing such as the apical biofilm and/or endogenous (cholesterol crystals) or exogenous (extruded endodontic materials that are indigestible or of difficult digestion) foreign bodies and that some cysts are reversible with endodontic treatment. We conclude that it is difficult for the clinician to adjust parameters defining a diagnosis of chronic inflammatory periapical lesions.

UNITERMS: Endodontics; Periapical cysts; Chronic inflammatory lesions.
\end{abstract}

\section{RESUMO}

objetivo deste estudo foi realizar uma avaliação comparativa entre os aspectos clínico-radiográficos e histopatológicos das lesões periapicais inflamatórias crônicas. Através deste, foram avaliadas 164 lesões inflamatórias crônicas periapicais provenientes de dentes de indivíduos, independendo de idade, raça e sexo. Foram encaminhados casos condizentes com periodontite apical crônica e processo cístico inflamatório avaliados através do exame clínico-radiográfico. Após procedimento cirúrgico, a análise histopatológica foi realizada. Os resultados clínico-laboratoriais foram submetidos à análise estatística. Os resultados mostraram que há constância de fatores de interferência na evolução do processo reparatório periapical representados com ênfase pelo biofilme microbiano apical e/ou por corpos estranhos tanto endógenos como os critais de colesterol quanto exógenos como os materiais endodônticos extravasados indigeríveis ou de difícil digestão; e que alguns processos císticos são passíveis de reversão com o tratamento endodôntico. Nesta pesquisa pode-se observar que é difícil para o clínico ajustar parâmetros definindo a hipótese diagnóstica das lesões periapicais inflamatórias crônicas.

UNITERMOS: Endodontia; Cisto periapical; Lesões inflamatórias crônicas.

\section{INTRODUCTION}

Representative inflammatory periradicular pathologies are universal and involve mainly the apical periodontium, with no predominance of race, sex or age ${ }^{12}$. They are transitional entities, meaning one type of lesion may transform into another.

Statistically significant factors have been reported concerning the prevalence of chronic apical periodontitis ${ }^{18}$; however, these pre-identified factors do not determine a definitive and accurate clinical and radiographic diagnosis. The lack of a conclusive definition of this inflammatory 
endodontic process frequently confuses the professional. Even when following the natural sequence, the reaction mechanisms of these pathologies are directly affected by local factors that may occur, qualifying the evolutionary phases, respecting peculiarities of the periapical region conditioned by the specificity of the periodontal complex ${ }^{9}$.

Structural and evolutionary variations of a periapical granuloma and radiographic aspects that are often undefined, observed in radicular cysts, are factors that hinder the clinical radiographic diagnosis of these osteolytic lesions.

Thus, the clinical radiographic diagnosis often disagrees with the histological diagnosis ${ }^{2,16,17,20}$. Historically, Bender and Seltzer have indicated that histological diagnosis of pulp tissue before root canal treatment is rendered cannot be obtained using clinical and radiographic examination.

Auxiliary diagnostic techniques of bone density have been tested, such as computerized tomography, leading to better diagnoses. Therefore, a cyst could be differentiated from periapical granulomas by computerized tomography because of a marked difference in density between the content of the cyst cavity and granulomatous tissue ${ }^{20}$.

The causes of inflammatory periapical pathologies are variable, including idiopathic and immunogenic responses as well as reactions to a foreign body. Therefore, it is common to observe these 3 reaction conditions concomitantly, acting in a specific way in the evolution of regional inflammation. This depends on periapical conditions such as the persistence of established microbiota (apical biofilm) and local modification such as those represented by the presence of cholesterol crystals (endogenous) and/or extravasated materials that may be indigestible (exogenous) ${ }^{9,14}$.

Considering the apical biofilm, the local environment determines the availability of growth factors for microorganisms, such as nutrients, oxygen and/or carbon dioxide tension, influencing the proliferative rhythm and the selectivity, synergism and competition between species ${ }^{4}$.

Inflammatory periodontal cysts (radicular cysts) derive from Malassez' epithelial rests involved during the evolution of periapical granulomas, characterized by an inflammatory process associated with the central cavity formation and limited by the stratified squamous epithelium, which may be discontinuous ${ }^{12,16}$.

The majority of these periapical granulomas and radicular cysts are occasionally found during routine examination. The smaller lesions are not distinguishable clinically and radiographically. A radiolucency of variable size can be observed with loss of the periapical lamina dura, with well- or ill-defined borders, with or without bone condensation involvement ${ }^{9,16,20}$.

Greater radiolucency together with perpendicular insertion can lead to a diagnosis of a cyst. However, oblique insertion indicates a diagnosis of periapical granuloma, but these data are not conclusive.

Therefore, the objective of this investigation was to comparatively assess differences between clinical, radiographic and histological examination results, in order to elucidate some of the shortfalls during the process of diagnosis, and to predictably identify possible post-treatment complications.

\section{MATERIALAND METHODS}

One hundred and sixty-four teeth diagnosed with chronic inflammatory periapical lesions, with or without previous nonsurgical endodontic treatment, were evaluated clinically and radiographically. Histological evaluation was obtained after surgical endodontic treatment. The patients were seen at the clinic of the Dental School of Ribeirão Preto, University of Ribeirão Preto, UNAERP. Endodontic surgery was conducted by staff endodontists, and biopsy specimens were sent to the pathology service of the same institution for histological evaluation and diagnosis determination. Semi-serial slices were obtained and stained with hematoxylin/eosin and Gomori trichrome for light microscopy evaluation.

To facilitate histological analysis of the samples, the following findings compatible with chronic apical periodontitis were considered: connective tissue with variable collagen density, inflammatory infiltrate predominantly of macrophages, lymphocytes, groups of plasmocytes, polymorphonucleocytes and giant cells, and presence of variable fibro-angioblastic proliferation that was epithelial or not. The lesions that presented connective tissue with variable diffuse inflammatory infiltrate and cavity formation limited by continuous or discontinuous stratified squamous epithelium were considered inflammatory cysts.

The data obtained were used for correlation between clinical, radiographic, and histological aspects to verify the occurrence of possible interference factors in the inflammatory evolution of chronic periapical lesions.

\section{RESULTS}

Of the 164 chronic inflammatory periapical lesions analyzed clinically and radiographically, 71 (43.29\%) were diagnosed as chronic apical periodontitis, 59 (35.98\%) as inflammatory cysts and 34 (20.73\%) had no definition. When histological evaluations were performed, 90 cases (54.88\%) were

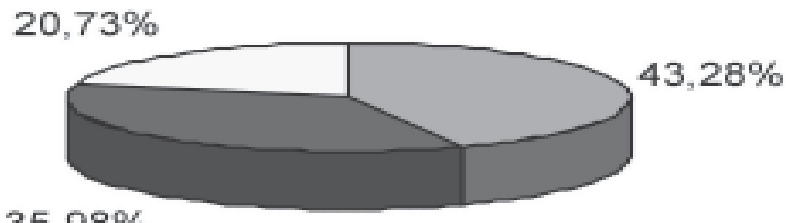

$35,98 \%$

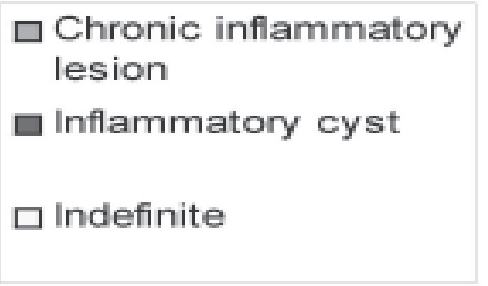

FIGURE 1- Percentage of chronic inflammatory lesions evaluated by clinical radiographic examination (164 cases) 


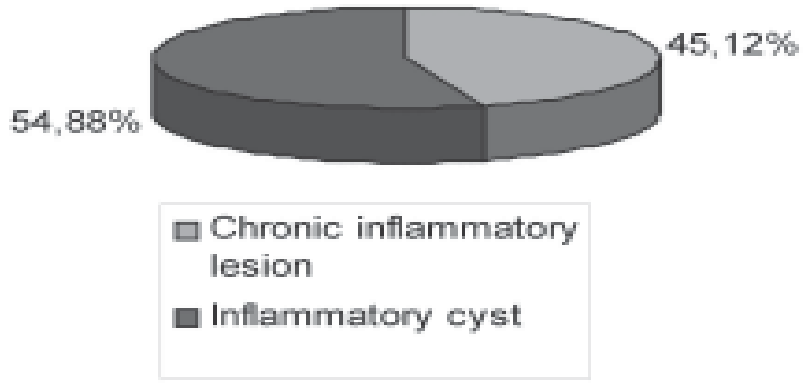

FIGURE 2- Percentage of chronic inflammatory lesions evaluated histologically (164 cases)
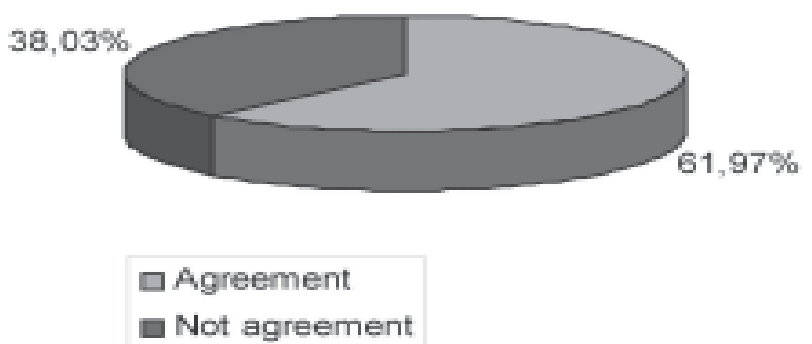

FIGURE 3- Percentage of agreements of diagnosis of chronic apical periodontitis after clinical radiographic versus histological analyses (71 cases)

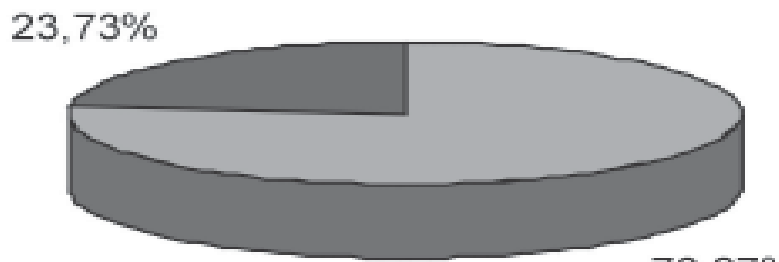

$76,27 \%$

\section{Agreement}

Not agreement

FIGURE 4- Percentage of agreements of diagnosis of inflammatory cyst after clinical radiographic versus histological examinations (59 cases)

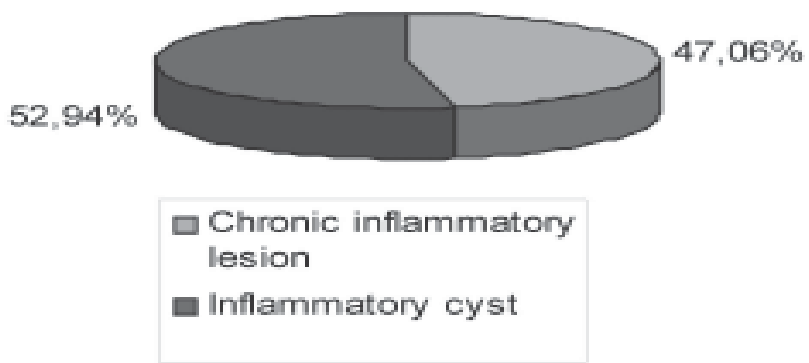

FIGURE 5- Percentage of chronic apical periodontitis and inflammatory cyst that were diagnosed only by the histological examination and not by clinical radiographic examination (34 cases) diagnosed as inflammatory cysts, 74 (45.12\%) as chronic apical periodontitis, and 2 presented a slight repair pattern. The results of the clinical radiographic and histological examinations are reported in Figures 1-5.

\section{DICUSSION}

The results of the present study were similar to those reported by several authors ${ }^{1,6,18}$; however, other authors have reported a higher incidence of periapical granuloma ${ }^{3,13,19}$. Literature has shown conflicting results for the incidence of these pathologies when evaluating lesions of extracted teeth with and without endodontic treatment and teeth with previous apicectomies and periapical curettage with previous root canal treatment.

When comparing the clinical and radiographic diagnosis with its respective histological analysis of 71 possible cases of chronic apical periodontitis, 44 were confirmed (61.97\% correlation), while of the 59 inflammatory cysts, 45 were confirmed (76.27\% correlation). These data are contrary to the results of Trope, et al. ${ }^{20}$ who reported a significant lack of agreement for eight lesions diagnosed clinically and radiographically as 4 inflammatory cysts and 4 chronic apical periodontitis. Histologically, only one was diagnosed as a radicular cyst.

The numbers obtained by histological examination of periapical granulomas and radicular cysts showed a higher possibility of diagnostic agreement for radicular cysts.

Of the 34 cases with no clinical radiographic definition, 16 (47.06\%) were diagnosed as chronic apical periodontitis and 18 (52.94\%) as inflammatory cysts. These data show a tendency of equivalence of occurrence of these pathologies.

Among the cases with previous non-surgical endodontic treatment, radicular cysts were more frequent; however, the persistence of periapical granuloma was also observed suggesting inefficient endodontic treatment, such as iatrogenic procedures and/or apical and periapical conditions, enhancing the possibility of not eliminating the apical biofilm and the presence of endogenous or exogenous foreign bodies, inducing constant reaction variables that interfere with the post-treatment repair process ${ }^{9}$.

Among the factors that hinder the evolution of repair, the presence of a persistent periradicular biofilm causes a nonspecific and immunogenic reaction ${ }^{8,9,14}$, which may be difficult to eliminate ${ }^{7}$. Endotoxin ${ }^{10}$ with lipid-A ${ }^{5,11}$, from vital or nonvital Gram-negative microorganisms, acts on the host cells, especially macrophages, leading to an uncontrolled and autodestructive reaction ${ }^{15}$.

The presence of foreign bodies, such as aggregated cholesterol crystals denominated colesteatomas ${ }^{9}$ and/or indigestible endodontic materials, leads to a macrophage reaction especially of giant cells. Zuolo, et al. ${ }^{21}$ showed the presence of glycosphingolipids in chronically inflamed tissue, totally absent in normal tissues. This is a condition that should always be considered in persistent chronic apical cases, which are relatively common.

Regarding inflammatory cysts, there was a high level of 
correlation between the clinical radiographic diagnosis and the histological diagnosis (76.27\%). On the other hand, $38.03 \%$ (27 cases) of lesions diagnosed as periapical granulomas by clinical radiographic examination, and 52.94\% (18 cases) without clinical radiographic diagnosis were histologically diagnosed as inflammatory cysts. This may lead to the conclusion that a reasonable percent of healing of such pathological processes occurs due to non-surgical endodontic treatment, with cystic involution as reported previously by several authors $2,9,12,16$.

The presence of apical biofilm and/or endogenous foreign bodies such as cholesterol crystals, or exogenous foreign bodies such as non-resorbable endodontic materials, can interfere with or prevent periapical healing after non-surgical endodontic treatment.

It must be emphasized that in this study the presence of epithelium without its characteristic cavity as a cystic process was not included in our data analysis. Instead, a periapical epithelial granuloma was considered. This could constitute extraneous factors, since periapical granulomas could evolve to a cystic lesion.

The results of this study showed a considerable degree of disagreement between the clinical radiographic and histological findings.

Due to the difficulty of clinical radiographic diagnosis, the first therapeutic option is conventional endodontic treatment and if the lesion persists after a period greater than two years of follow-up, surgical treatment should recommended. It is important to point out that in this case the removed lesion should be examined histologically because this diagnosis is important for definition of the case.

\section{CONCLUSION}

According to the experimental conditions and the results obtained, the following can be concluded:

- Dentists, unable to establish histological diagnosis of their cases, are often misled by the clinical and radiographic findings and fail to provide their patients with an adequate rationale for treatment failure, which normally involves indication for further procedures, such as surgical endodontic treatment or apical curettage.

\section{REFERENCES}

1- Baskar SN. Periapical lesions - types, incidence and clinical features. Oral Surg Oral Med Oral Pathol 1966;21:657-71.

2- Baskar SN. Nonsurgical resolution of radicular cysts. Oral Surg Oral Med Oral Pathol 1972;34:458-68.

3- Block RM, Bushell A, Rodrigue H, Langeland K. A histopathologic, histobacteriologic and radiographic study of periapical endodontic surgical specimens. Oral Surg Oral Med Oral Pathol 1976;42:65678.
4- Dahlen G, Möller JR. Microbiology of Endodonticinfections. In: Nolte WA, editors. Oral microbiology with basic microbiology and immunology. 4th ed. St Louis: Mosby; 1992.

5- Galanos C. Physical state and biological activity of lipopolysaccharides. Toxicity and immunogenecity of the lipid A component. Z. Immun-Forsch Bd 1975;149 p. 214-29.

6- Lalonde ER, Luebke RG. The frequency and distribution of periapical cysts and granulomas. Oral Surg 1968;25:861-8.

7- Leonardo MR Rossi MA, Silva LA, Ito IY, Bonifacio KC. Evaluation of bacterial biofilm and microorganisms on the apical external root surface of human teeth. J. Endod 2002; 28:815-8.

8- Leonardo MR, Salgado AA, Silva LA, Tonomaru Filho M. Apical and periapical repair of dog's teeth with periapical lesions after endodontic treatament with different root canal sealer. Pesqui Odontol Bras 2003;1:69-74.

9- Lia RCC Patologias periapicais inflamatórias: bases biológicas. In: Cardoso, RJA, Gonçalves EAN, editors. Odontologia: Endodontia /Trauma. São Paulo: Artes Médicas; 2002. p.15-37.

10- McGEE JOD, Isaacson PG, Wright NA. Oxford Textbook of Pathology. Principles of pathology. Oxford: University Press; 1992.

11- Morrison B, Kline L. Activation of the classical and properdin pathways of complement by bacterial lipopolysaccharides (LPS). J. Immunol 1977;118:362-8.

12- Neville BW, Damm DD, Allen .M, Bouquot JE. Patologia oral \& maxilofacial, Rio de Janeiro: Ed. Guanabara Koogan; 1998.

13- Patterson SS, Shafer WG Healey HJ. Periapical lesions associated with endodontically treated teeth. J Am Dent Assoc 1964;68:191-4.

14- Pulver WH, Taubman MA, Smith DJ. Immune components in human dental periapical lesions. Arch Oral Biol 1978;23:435-43.

15- Reitschel ET, Brade H. Bacterial endotoxins. Sci Am 1992;267:26-33

16- Shear M. Cystos da região bucomaxilofacial: diagnóstico e tratamento. 3th ed. São Paulo: Ed. Santos; 1999.

17- Simon JHS. Incidence of periapical cysts in relation to the root canal. J Endod 1980; 6:845-8.

18- Spatafore CM, Griffin JAJr, Keyes GG, Wearden S, Skidmore AE. Periapical biopsy report: an analysis of over a 10-year period. J Endod 1990;16:239-41.

19- Stockdale CR, Chandler NP. The nature of periapical lesion: a review of 1108 cases. J Dent 1988;16:123-9.

20- Trope M, Pettigrew J, Petras J, Barnett F, Tronstad L. Differentiation of radicular cysts and granulomas using computerized tomography. Endod Dent Traumatol 1989;5:69-72.

21- Zuolo ML, Toledo MS, Nogueira HE, Straus AH, Takahashi HK. Identification of GM3 as a marker of therapy-resitant periradicular lesions. J Endon 2001;27:107-9. 